\section{ARTIST MIKOLAY DAVIDOVYCH AND COUNTS BRANICKI}

\author{
Nikita Dmytrenko, \\ https://orcid.org/0000-0002-5002-9405 \\ Postgraduate student \\ of the Department \\ of Theory and History of Art, \\ National Academy \\ of Fine Arts and Architecture, \\ Kyiv, Ukraine \\ nik.dmitrenko.1993@gmail.com
}

\section{ХУДОЖНИК МІКОЛАЙ ДАВІДОВИЧ ТА ГРАФИ БРАНИЦЬКІ}

Нікіта Дмитренко,

https://orcid.org/0000-0002-5002-9405

аспірант кафредри теорії

та історії мистецтва,

Національна академія

образотворчого мистецтва

і архітектури,

Київ, Україна

nik.dmitrenko.1993@gmail.com

\section{Abstract}

The aim of the research is to study available information about life and creative work of an artist (painter, graphic artist) Mikolay Davidovych, determining the place of his works in the collection of Counts Branicki of the Korczak Coat of Arms, determining possible ways of further search for materials for studying his creative work. Research methodology. Methods of art and historical analysis were used. Scientific novelty. In the paper the creative work of Polish artist Mikolay Davidovych coming from Ukraine (was born in Ustymivka village located in Kyiv region) is studied for the first time based on the materials found in the course of studies of the collection of Counts Branicki. Conclusions. Mikolay Davidovych, a painter and graphic artist, studied at Kraków Academy of Fine Arts (1884-1888), actively participated in exhibitions of the Society for the Encouragement of Artists of Kraków and Warsaw. The main genre in which the artist worked was portrait. He worked for prosperous aristocratic families (painting portraits of Counts Branicki of the Korczak Coat of Arms, princes Sanguszko). He worked in Kraków, Warsaw, Tarnów (Poland). Mikolay Davidovych spent a considerable part of his life and creative work in BilaTserkva (Ukraine). Currently works of Mikolay Davidovych are kept in the Museum of King Jan III's Palace at Wilanów (Warsaw, Poland), Museum of Tarnów (Lesser Poland Voivodeship, Poland) and Bila Tserkva Country Studies Museum.

\section{Анотація}

Мета дослідження. Опрацювання знайдених відомостей про життя та творчість художника (живописця, графіка) Міколая Давідовича, визначення місця його творів у колекції графів Браницьких герба Корчак, з'ясування можливих шляхів пошуку матеріалів для дослідження його творчості надалі. Методологія дослідження. Використовувалися методи мистецтвознавчого та історичного аналізу. Наукова новизна. У статті вперше проводиться дослідження творчості польського художника Міколая Давідовіча, що походить з України (нар. В с. Устимівка, що на Київщині) на основі знайдених під час дослідження колекції графів Браницьких матеріалів. Висновки. Міколай Давідович, живописець і графік, навчався у Краківській академії мистецтв (1884-1888), брав активну участь у виставках товариства заохочування художників Кракова та Варшави. Основним жанром, у якому працював художник, був портрет. Він писав на замовлення заможних аристократичних родин (портретування графів Браницьких герба Корчак, князів Сангушків). Працював у Кракові, Варшаві, Тарнові (Польща). Значний період свого життя та творчості Міколай Давідович провів у Білій Церкві (Україна). Нині твори Міколая Давідовича зберігаються у Музеї короля Яна III у Вілянуві (Варшава, Польща), музеї м. Тарнова (Малопольське воєводство, Польща) та Білоцерківському краєзнавчому музеї. 


\section{Keywords: Ключові слова:}

Mikołaj Dawidowicz, Counts Branicki of the Міколай Давідович, графи Браницькі герба Korczak Coat of Arms, art collection, portrait, Корчак, художня колекція, портрет, живопис, painting, graphics, city of Bila Tserkva.

графіка, місто Біла Церква.

Вступ 1 Ім'я польського художника Міколая Давідовича, який походив з України та певний час свого творчого життя працював у Білій Церкві, згадується в окремих польських виданнях, у музейних документах України та Польщі. Портретні твори художника нині зберігаються у Білоцерківському Краєзнавчому музеї, у Музеї короля Яна III у Вілянуві (Варшава, Польща), у Музеї міста Тарнова (Польща). Однак, сьогодні ми не маємо досліджень про життя та творчість художника. Всі факти, які були опубліковані, звужуються до короткого переліку хронологічних відомостей та згадування окремих творів. Тим не менше, роботи Міколая Давідовича на замовлення аристократичних родин (графи Браницькі, князі Сангушки), участь художника у виставках Товариства друзів образотворчого мистецтва (польською - Towarzystwo przyjaciół sztuk pięknych), свідчить про достатньо високий професійний і творчий рівень майстра.

Особливу зацікавленість у дослідженні життя та творчості М. Давідовича викликає той факт, що за певними даними художник народився на Київщині та тривалий час (з часів Першої світової війни та принаймні до 1931 року) перебував в Україні, в тому числі після створення Білоцерківського краєзнавчого музею працював з його портретними замовленнями. Сьогодні польські дослідники мистецтва відносять Міколая Давідовича одночасно до представників польського та українського (часів входження України до складу Російської імперії) мистецтва. Дослідження життя та творчості Міколая Давідовича дозволить доповнити картину українського мистецького життя кінця XIX - першої третини XX століття, а також розширити уявлення про портретну частину приватної колекції графів Браницьких герба Корчак (коло авторів творів).

Мета 2
дослідження

Метою даного дослідження є опрацювання знайдених відомостей про життя та творчість художника Міколая Давідовича, визначення місця його творів у колекції графів Браницьких герба Корчак, з'ясування можливих шляхів пошуку матеріалів для дослідження його творчості й надалі.

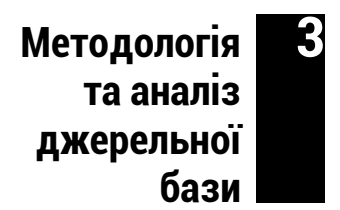

Під час проведення досліджень використовувалися методи мистецтвознавчого та історичного аналізу на базі знайдених відомостей про життя аристократичних родин (Браницькі, Сангушки) в Україні та Польщі XIX - початку XX ст., а також знайдених за темою дослідження творів мистецтва у фондах музеїв України і Польщі. Публікацій, присвячених Міколаю Давідовічу, 
Деміург: ідеї, технології, перспективи дизайну 2019 Том 2 № 1 Demiurge: ideas, technologies, perspectives of design 2019 Vol. 2 No 1

відомостей про дослідження життя та творчості цього художника нам знайти не вдалося (пошук проводився у науковому і публіцистичному просторі не лише України і Польщі, але й інших країн). За роки існування Білоцерківського краєзнавчого музею дослідження на цю тему не проводились. Перший виступ з доповіддю за даною темою відбувся 14 червня 2018 року на XLII Краєзнавчих читаннях імені отця Петра Лебединцева в Білоцерківському краєзнавчому музеї. Текст виступу був опублікований у Білій Церкві (Дмитренко, 2018). Робота виконана в рамках наукових досліджень кафедри теорії та історії мистецтва Національної академії образотворчого мистецтва і архітектури з вивчення приватної художньої колекції графів Браницьких.

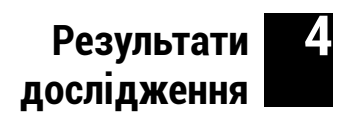

Першим поштовхом до початку пошукової роботи з вивчення життя та творчості художника Міколая Давідовича була знахідка портрету Ксаверія Браницького у фондах Музею палацу короля Яна III у Вілянуві (Варшава, Польща). На портреті зображений Ксаверій-Владислав-Олександр-Костянтин-АнджейЛеон Браницький (1864-1926), син графа Костянтина-Ґжеґожа та Ядвіги з Потоцьких (рис. 4.1).

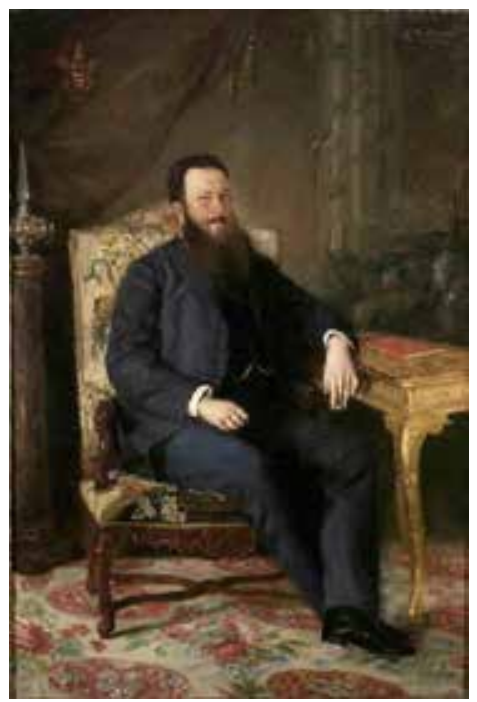

Рис. 4.1. М. Давідович. Портрет Ксаверія Браницького, 1910. 175 × 124 см. Полотно, олія. Музей короля Яна III, Вілянув, Варшава, Польща.

Fig. 4.1. M. Davydovich. Portrait of Xavier Branicki, 1910. $175 \times 124 \mathrm{~cm}$ Canvas, oil. Museum of King Jan III, Vilyanov, Warsaw, Poland.

Ксаверій Браницький народився та виріс у Парижі, але з дитинства часто їздив до Білої Церкви в Україну. За родинними свідченнями, він захоплювався цим чудовим краєм. Згодом у Турчинові (недалеко від Білої Церкви, між Медвином та Ставищами) він побудував заміський палац (після 1917 року палац було пограбовано та повністю зруйновано), був міцно пов'язаний з Україною. У 1886 році одружився з Анною Потоцькою, яка була його сестрою по лінії тітки. Під час медового місяця подружжя спостерігало за будівництвом у Турчинові. Цікаво 
те, що архітектором палацу (план був створений у 1889-х 1890-х рр.) був поляк Леандро Марконі (Leandro Markoni) (1834-1919). Саме Марконі згодом займався ремонтом та реконструкцією (добудовами) палацу у Вілянові після того, як цей палац після смерті Олександри-Юлії Потоцької перейшов у спадщину до Ксаверія Браницького (1892). Після отримання палацу Браницький оселяється у Вілянуві, а до України приїджає епізодично. 31901 року Ксаверій живе у Варшаві на вул. Новий Світ у будинку, який він придбав. 3 цього часу палац у Вілянові стає його літньою резиденцією. Сам будинок до цього належав білоцерківчанці Мірії-Анелії-Ружі Браницькій з Сапег (1843-1912). Ксаверій Браницький вважався одним з найкультурніших людей свого часу (був бібліофілом, знавцем малярства, опікувався Варшавською філармонією) (Чернецький, 2011).

Міколай Давідович зобразив Ксаверія Браницького, що сидить у м'якому розкішному кріслі біля різьбленого, вкритого позолотою столу, на який граф поклав ліву руку. На столі лежить книга у червоній обкладинці. Граф знаходиться у своєму кабінеті в палаці у Вілянуві: на підлозі килим, на стіні, що декорована шторою з китицями герба Корчак, зліва зображена інтер'єрна колона червоного мармуру, на якій стоїть срібний канделябр художньої роботи. На постать графа падає природне денне світло з лівого боку. Загалом портрет має контрастний за світлотою колорит, у якому на загальному темному тлі (стіни інтер'єру, одяг) увага глядача концентрується на обличчі та кистях рук портретованого, а також достатньо освітлених елементах інтер'єру (крісло, стіл, килим на підлозі), що підкреслює розкішне облаштування кабінету. У верхньому правому куті полотна розташований автограф художника «M. Dawidowicz. Wilanów». Портрет виконано олійними фарбами на полотні розміром 175 × 124 см. У музейних описах він датований 1910 р. і належить пензлю Міколая Давідовича (номер за музейним каталогом: Wil.1385).

Наукові співробітники музею Яна III не мають відомостей про художника. Так, дослідниця Кароліна Алкемаде висловила думку про те, що позначений у документах польський художник Міколай Давідович також зачислявся до представників російського живопису. На її думку, відсутність достатніх відомостей про художника в Польщі пояснюється тим, що Міколай Давідович міг тривалий час працювати на теренах України, яка входила до складу Російської імперії. Підтвердженням цього припущення є сам факт портретування Ксаверія Браницького, який, хоч і відбувся у Вілянуві у 1910 р., але передбачав можливу роботу Давідовича на замовлення Браницьких вже у їхніх маєтках в Україні і, перш за все, в основному графському маєтку у Білій Церкві. Під час роботи у фондах Білоцерківського краєзнавчого музею ми вже зустрічали твори авторства художника М. Давідовича. Цікавим $€$ те, що у «Списі придбань у галузі 
мистецтва» (Білоцерківський музей старожитностей, 1925), складеному завідувачем Окружного музею Дроздовим та зберігачем музею Дідківським 1 червня 1925 р. (зберігається у Білоцерківському краєзнавчому музеї) запис № 66 містить напис прізвища художника, а саме «Давідович» - з літерою «і». Тобто це збігається з транскрипцією польського написання прізвища у Вілянуві. В той же час, у інших музейних книгах опису творів ми зустрічаємо напис «Давидович» через літеру «и». Повного написання ім'я художника у білоцерківських записах ми не знаходимо, лише першу літеру «М». Вона співпадає з іменем польською мовою «Міколай», або українською «Микола». Вперше в історії Білоцерківського краєзнавчого музею виникає питання: чи є Міколай Давідович (автор портрету Ксаверія Браницького) та М. Давідович [Давидович] (автор творів у фондах білоцерківського краєзнавчого музею) однією особою? Якщо так, то до 30-х рр. XX ст. художник Міколай Давідович, автор портрету Ксаверія Браницького 1910 року, перебував у Білій Церкві та виконував портретні замовлення музею. Портретний жанр згаданих у документах Білоцерківського краєзнавчого музею творів М. Давідовича (живопис, графіка) дає нам підстави припустити, що у Білій Церкві перебував саме Міколай Давідович.

Проаналізувавши документи Білоцерківського краєзнавчого музею (йдеться про описи творів образотворчого мистецтва), ми дійшли висновку, що свого часу в музеї зберігалося принаймні 8 робіт М. Давідовіча - це живописний портрет Карла Маркса (№ 0226, запис 05.01.1925), портрет п.о. (62 × 46) (Білоцерківський музей старожитностей, 1925) надійшов від автора та виконаний на замовлення у 1930-му (можливо, у 1931р.), графічні, виконані графітним олівцем на папері, портрети українських гетьманів (Петра Конашевича Сагайдачного, Самойловича, Мазепи, Хмельницького, Дорошенка, Полуботка). На жаль, рівень складання тогочасних документів надзвичайно низький і для мистецтвознавчого дослідження користування лише цими записами не є достатнім. Тому ми вважаємо, що пошук відомостей про цього польського, українського або російського портретиста Міколая Давідовича та його зв'язок з портретними замовленнями Браницьких герба Корчак та про можливий факт перебування творів саме цього художника в довоєнні часи у Білоцерківському краєзнавчому музеї є актуальним і потребує ретельної праці. Наведемо відомості про твори М. Давідовича у фондах Білоцерківського краєзнавчого музею, що записані у трьох книгах (прим.: наводимо записи дослівно):

«Книга 1924-1924 рр. 0226 05.01.1925. Портрет Карла Маркса. п.о. 62 × 46. Давидович М. Придбано. Давидович був у Б. Церкві 1924-25 р., портретист, помер в Польщі 1927 р.; 12781930 Картина Портрет Петра Конашевича Сагайдачного, папір; 12791930 Картина, папір; 12801930 Картина, папір; 1281 1930 Картина, папір; 12821930 Картина, папір; 12831930 Кар- 
тина, папір; 12841930 Картина, папір; 2408 (2136) 1931 Портрет гетьмана Самойловича, дерев'яна рама, папір, М. Давидович; 2409 (2137) 1931 Портрет гетьмана Сагайдачного, дерев'яна рама, папір, М. Давидович; 2410 (2138) 1931 Портрет гетьмана Мазепи, дерев'яна рама, папір, М. Давидович; 2411 (2139) 1931 Портрет гетьмана Хмельницького, дерев'яна рама, папір, М. Давидович; 2412 (2140) 1931 Портрет гетьмана Полуботка, дерев'яна рама, папір, М. Давидович; 2413 (2141) 1931 Портрет гетьмана Дорошенка, дерев'яна рама, папір, М. Давидович; Книга 1937-1946 рр. 70 Малюнок Портрет Богдана Хмельницького 313 картон, олівець; 77 Малюнок Гетьман Самойлович 341 папір, олівець , 130х66. Книга 1948-1961рр. 0034300217 Малюнок. Портрет гетьмана Хмельницького, 1931, Замовлення KB-01, 1948.02.28; 00351002200024 Малюнок Портрет гетьмана Самойловича, 1931. Замовлення КВ-01 1948.02.28; 01119 00304 Малюнок Портрет гетьмана Мазепи, 1931. Замовлення КB-01 1948.03.20; 0112000305 Малюнок Портрет гетьмана Дорошенка, 1931. Замовлення КВ-01 1948.03.20; 0112100306 Малюнок Портрет гетьмана Полуботка, 1931. Замовлення КВ-01 1948.03.20; 0112200307 Малюнок Портрет гетьмана Сагайдачного, 1931. Замовлення КВ-01 1948.03.20» (Книга обліку, 19241930; Спис придбань в галузі мистецтва, 1925).

У пошуках відомостей про Міколая Давідовича у липні 2018p. ми відвідали музей Краківської академії образотворчих мистецтв (Akademia Sztuk Pięknych w Krakowie). У бібліотеці музею було знайдено довідкове видання «Матеріали з історії Академії образотворчих мистецтв у Кракові 1816-1895 рр.» (10 том «Джерела історії мистецтва Польщі», виданий Національним Товариством ім. Оссолінських у Вроцлаві у 1959 році). У ньому наводяться короткі відомості про художника М. Давідовича: народився у с. Устимівка (Україна), у 1884-1888 навчався у Школі образотворчих мистецтв (Szkoła Sztuk Pięknych) - саме таку назву до 1900 р. мала сучасна Академія образотворчих мистецтв ім. Яна Матейки у Кракові (Akademia Stuk Pięknych im Jana Matejki w Krakowie). у 1886 р. отримав грошову премію за академічний етюд оголеної натури та першу винагороду за скульптурне моделювання голови людини (Ryszkiewiecza, 1959). У пошуках відомостей про участь Давідовича у виставках під час його перебування у Кракові ми звернулися до Палацу Мистецтв у Кракові (Palac-Sztuki w Krakowie). Нам вдалося знайти у фондах палацу декілька видань про тогочасні виставки Товариства друзів образотворчого мистецтва, на яких виставлялися твори М. Давідовича. У звіті дирекції об'єднаного Товариства друзів образотворчого мистецтва в Кракові за 1885 рік (Sprawozdanie Dyrekcyi Zjednoczonego, 1886) під номером 63 вказується малюнок «3 життя художника».

У Каталозі постійної виставки Товариства друзів образотворчого мистецтва у Кракові в Сукеніцах, виданий у 1889 р. (Katalog nieustającej wystawy, 1889), під № 53-55 вказано три 
портрети авторства М. Давідовича: «Портрет Мауріція Манна» (Maurycego Manna), Луціна Семінського (Lucyana Siemińskiego), Александра Шукевича (Aleksandra Szukiewicza). Вказано, що усі три портрети є малюнками, виконаними крейдою, і $є$ приватною власністю. У звіті дирекції об'єднаного Товариства друзів образотворчого мистецтва у Кракові за 1889 р. (Sprawozdanie Dyrekcyi Zjednoczonego, 1890) вказано про участь п'яти портретів авторства М. Давідовича, вони записані під номерами 55-59: Портрет М. Манна (M. Manna); Портрет А. Шукевича (A. Szukiewicza); Портрет Л. Семінського (L. Siemieńskiego); Портрет Я. І. Крашевського (J.I. Kraszewskiego) (чотири портрети виконані крейдою на папері, а також «Портрет людини» (матеріал виконання не вказаний)). Тобто, згідно зі звітом Товариства у 1889 р., ще два твори Давідовича (крім вказаних у каталозі виставки у Сукеніцах) виставлялися у Кракові. У звіті дирекції об'єднаного Товариства друзів образотворчого мистецтва в Кракові за 1903 р. (Sprawozdanie Dyrekcyi Zjednoczonego, 1904) під номером 13 вказано «Портрет чоловіка». Ми навели знайдені нами відомості про участь Міколая Давидовича у виставках Товариства друзів образотворчого мистецтва у Кракові. Нам відомо про участь художника й у виставках Товариства друзів образотворчого мистецтва у Варшаві в 1884, 1896, 1898, 1900 та 1901 рр. Дослідження про участь у цих виставках попереду.

Безумовно, цікавою для дослідження є робота Давідовича над портретними замовленнями представників тогочасної аристократії. Зв'язок М. Давідовича з графами Браницькими не був випадковістю, адже художник народився в Устимівці неподалік від Білої Церкви на Київщині, на землях, які входили до складу Устимівських маєтків графів Браницьких. Сьогодні ми не маємо відомостей про те, чи сприяли Браницькі художньому навчанню Міколая Давідовича в Краківський школі образотворчих мистецтв, але це могло бути цілком вірогідно.

Під час навчання у Кракові М. Давідович отримував фінансову допомогу від князя Романа Даміана Сангушка (Sołtys, 2016). Відомо також про піклування з боку князя Романа Даміана Євстахія Павла Сангушко над польським художником українського походження Влодимиром Лощем (Włodzimierz Łoś). Він також навчався у 70-ті pp. XIX ст. у Краківській школі образотворчого мистецтва, отримуючи стипендію від князя Сангушка. Графи Браницькі та князі Сангушки мали родинні зв'язки (ще донька графа Францишка-Ксаверія Браницького Катажина у першому шлюбі була дружиною Костянтина Сангушка (1781-1808) (Чернецький, 2011), відомі непоодинокі приклади спілкування, ведення спільних господарчих справ та інше (Чернецький, 2011).

У пошуках творів Давідовіча ми відвідали Музей Тарнова (м. Тарнов, Малопольське воєводство, Польща). У постійній експозиції у міській ратуші у так званому «залі зі сріблом» 
експонується портрет князя Романа Даміана Сангушка, написаний Міколаєм Давідовічем у 1896 році (рис. 4.2.).

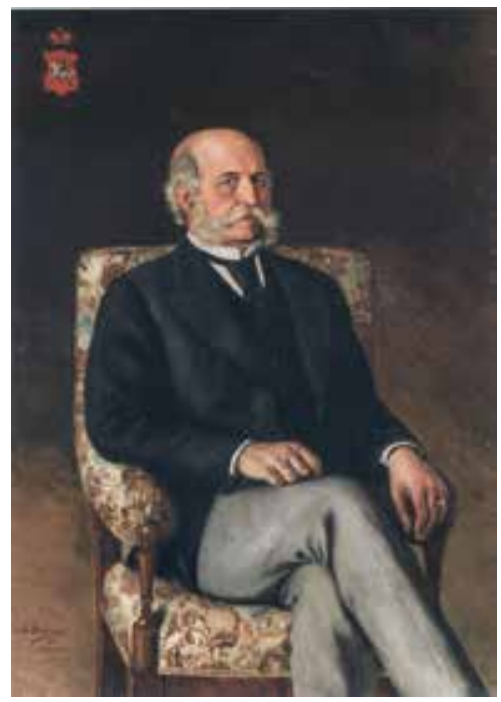

Рис. 4.2. М. Давідович.

Портрет Романа Даміана Сангушка, 1896.

132,5 x 94 см. Полотно, олія. Музей Тарнова

(Тарнів, Малопольське воєводство, Польща).

Fig. 4.2. M. Davydovich.

Portrait of Roman Damian Sangushka, 1896.

132.5 x $94 \mathrm{~cm}$. Canvas, oil. Tarnow Museum

(Tarnow, Lesser Poland Voivo deship, Poland).

Портрет зображує князя, що сидить у кріслі. Колорит, манера виконання портрета схожа на «вілянівський» портрет Браницького. Також у лівому верхньому куті розташований герб «Погоня», до якого належали князі Сангушки. У портреті Сангушка інша композиція: з елементів інтер'єру - лише крісло з вкритою візерунками оббивкою, а фігура портретованого зображена до колін. Портрет виконаний олійними фарбами на полотні розміром 132,5 × 94 см. У лівому нижньому куті автограф: «M. Dawidowicz 96 Sławuta». 3 цього ми дізнаємося, що портрет був написаний у маєтку Сангушка у Славуті (на Волині, Україна). Отже, пошуки творів М. Давідовіча в музейних зібраннях Польщі та України тривають.

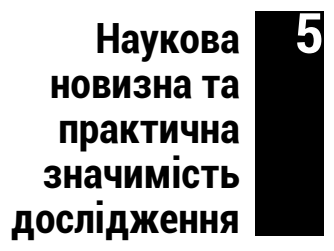

У статті вперше викладені знайдені відомості про творчість живописця і графіка українського походження Міколая Давідовича, твори якого входили до складу мистецьких колекцій графів Браницьких, князів Сангушків і картини якого нині зберігаються у музеях Польщі та України.

Висновки 6

Живописець і графік Міколай Давідович навчався у Краківській академії мистецтв (1884-1888) (на той час - Школа образотворчих мистецтв міста Кракова), брав активну участь у виставках товариства заохочування художників Кракова та Варшави.

Основним жанром, у якому працював художник, був портрет. Він працював на замовлення заможних аристократичних родин (портретування графів Браницьких герба Корчак, князів Сангушків). 
Працював у Кракові, Варшаві, Тарнові (Польща). Значний період життя та творчості Міколай Давідовіч провів у Білій Церкві. Нині твори художника зберігаються у Музеї короля Яна III у Вілянуві (Варшава, Польща), музеї м. Тарнова (Малопольське воєводство, Польща), Білоцерківському краєзнавчому музеї.

\section{Список бібліографічних посилань}

Дмитренко, Н. (2018). Твори художника Міколая Давідовича у зібранні графів Браницьких. В Краєзнавчі читання імені о. Петра Лебединцева: видання Білоцерківського краєзнавчого музею (Вип. XLII, с. 39-45). Біла Церква.

Книга обліку. (1924-1930). Фонд комунального закладу Київської обласної ради Білоцерківського краєзнавчого музею. Біла Церква.

Спис придбань в галузі мистецтва. (1925, 1 червня). Фонд комунального закладу Київської обласної ради Білоцерківського краєзнавчого музею (В УАК 46/2а УССР). Архів і бібліотека. Білоцерківський музей старожитностей, Біла Церква.

Чернецький, Є.А. (2011). Браницькі. Біла Церква: Видавець Пшонковський О.В.

Katalog nieustającej wystawy Towarzystwa przyjaciół stuk pięknych w Krakowie w Sukiennicach. (1889). (Nr. 4. Wdrukarni «Czasu» Fr. Kluczyckiego i Sp. Pod zarządem Józefa Łakocińskiego). Nakladem Towarzystwa przyjaciół sztuk pięknych, Krakow.

Ryszkiewiecza, A. (Red.). (1959). Żrodla do dzieów Stuki Polskiej. W J.E. Dutkiewicza, J. JeleniewskaŚlesińska, W. Ślesiński, A. Załuski (Red.), Materyły do dzieów Akademii Stuk Pięknych w Krakowie. 1816-1895. Wrocław: Wydawnictwo Zakładu Narodowogo im. Ossolińskich.

Sołtys, K. (2016). Sanguszkowie. Katalog Wystawy Stałej. Tarnów: Tarnowskie Towarzystwo Kulturalne.

Sprawozdanie Dyrekcyi Zjednoczonego Towarzystwa przyjaciół sztuk pięknych w Krakowie z czynności za rok 1885. (1886). (Rok XXXI. W drukarni «Czasu» Fr. Kluczyckiego i Sp. Pod zarządem Józefa Łakocińskiego). Nakladem Zjednoczonego Towarzystwa przyjaciół sztuk pięknych, Krakow.

Sprawozdanie Dyrekcyi Zjednoczonego Towarzystwa przyjaciół sztuk pięknych w Krakowie z czynności za rok 1889. (1890). (Rok XXXV. W drukarni «Czasu» Fr. Kluczyckiego i Sp. Pod zarządem Józefa Łakocińskiego). Nakladem Zjednoczonego Towarzystwa przyjaciół sztuk pięknych, Krakow.

Sprawozdanie Dyrekcyi Zjednoczonego Towarzystwa przyjaciół sztuk pięknych w Krakowie z czynności za rok 1903. (1904). (Rok XXXIX. W drukarni «Czasu» Fr. Kluczyckiego i Sp. Pod zarządem Józefa Łakocińskiego). Nakladem Zjednoczonego Towarzystwa przyjaciół sztuk pięknych, Krakow.

\section{References}

Chernetskyi, Ye.A. (2011). Branytski [Branches]. Bila Tserkva: Vydavets Pshonkovskyi O.V. [in Ukrainian].

Dmytrenko, N. (2018). Tvory khudozhnyka Mikolaia Davidovycha u zibranni hrafiv Branytskykh [Works of the artist Nikolai Davydovich in the collection of Count Branicki]. In Kraieznavchi chytannia imeni ottsia Petra Lebedyntseva: vydannia Bilotserkivskoho kraieznavchoho muzeiu [Local linguistic reading of the name of Father Petro Lebedintsev: edition of the Bila Tserkva Local History Museum] (Issue XLII, pp. 39-45). Bila Tserkva [in Ukrainian].

Katalog nieustającej wystawy Towarzystwa przyjaciół stuk pięknych w Krakowie w Sukiennicach [The catalog of the most up-to-date newsstands will be used to create stuck books in Krakow in Sukiennicach]. (1889). (Nr. 4. Wdrukarni "Czasu" Fr. Kluczyckiego i Sp. Pod zarządem Józefa Łakocińskiego). Nakladem Towarzystwa przyjaciół sztuk pięknych, Krakow [in Polish]. 
Knyha obliku [Book of accounting]. (1924-1930). Fond komunalnoho zakladu Kyivskoi oblasnoi rady Bilotserkivskoho kraieznavchoho muzeiu. Bila Tserkva [in Ukrainian].

Ryszkiewiecza, A. (Ed.). (1959). Żrodla do dzieów Stuki Polskiej [Żrodla do dziełw Stuki Polskiej]. Tom X. In J.E. Dutkiewicza, J. Jeleniewska-Ślesińska, W. Ślesiński, A. Załuski (Eds.), Materyły do dzieów Akademii Stuk Pięknych w Krakowie. 1816-1895 [Materials for the Academy of Sciences of the Stuka of Pięknych in Krakow. 1816-1895]. Wrocław: Wydawnictwo Zakładu Narodowogo im. Ossolińskich [in Polish].

Sołtys, K. (2016). Sanguszkowie. Katalog Wystawy Stałej [Sanguszkowie Catalog Wystawy Stałej]. Tarnów: Tarnowskie Towarzystwo Kulturalne [in Polish].

Sprawozdanie Dyrekcyi Zjednoczonego Towarzystwa przyjaciół sztuk pięknych w Krakowie z czynności za rok 1885 [Spreading the Dyrekcyi Zjednoczonego Towarzystwa przyjaciół zzęk družkychych w Krakowie z znakowe za rok 1885]. (1886). (RokXXXI. W drukarni «Czasu» Fr. Kluczyckiego i Sp. Pod zarządem Józefa Łakocińskiego). Nakladem Zjednoczonego Towarzystwa przyjaciół sztuk pięknych, Krakow [in Polish].

Sprawozdanie Dyrekcyi Zjednoczonego Towarzystwa przyjaciół sztuk pięknych w Krakowie z czynności za rok 1889 [Sprawozdanie Dyrekcyi Zjednoczonego Towarzystwa przyjaciół zzęk drobnych w Krakowie z znaczu za rok 1889]. (1890). (Rok XXXV. W drukarni "Czasu" Fr. Kluczyckiego i Sp. Pod zarządem Józefa Łakocińskiego). Nakladem Zjednoczonego Towarzystwa przyjaciół sztuk pięknych, Krakow [in Polish].

Sprawozdanie Dyrekcyi Zjednoczonego Towarzystwa przyjaciół sztuk pięknych w Krakowie z czynności za rok 1903 [Sprawozdanie Dyrekcyi Zjednoczonego Towarzystwa przyjaciół zzęk drobnych w Krakowie z znakomstwo za rok 1903]. (1904). (Rok XXXIX. W drukarni «Czasu» Fr. Kluczyckiego i Sp. Pod zarządem Józefa Łakocińskiego). Nakladem Zjednoczonego Towarzystwa przyjaciół sztuk pięknych, Krakow [in Polish].

Spys prydban $\vee$ haluzi mystetstva [List of acquisitions in the field of art]. (1925, June 1). Fond komunalnoho zakladu Kyivskoi oblasnoi rady Bilotserkivskoho kraieznavchoho muzeiu (V UAK 46/2a USSR). Arkhiv i biblioteka. Bilotserkivskyi muzei starozhytnostei, Bila Tserkva [in Ukrainian]. 